matics and didactics. The Unione Matematica Italiana cannot offer any financial assistance to visitors; but it is expected that expenses for the stay at Pisa will be low. All inquiries relating to the Congress should be sent to Prof. Luigi Berzolari, Universitá di Bologna, Bologna, president of the Unione Matematica Italiana, who is acting as secretary to the Congress.

\section{British Thomson-Houston Summer School}

THE British Thomson-Houston Co., Ltd., Rugby, is holding a summer school in electrical engineering during July 12-16. Sir Henry Tizard is to open the school, which will consist of lectures and discussions on such topics as electronic control of motors, magnetic sheet steel, examination of large forgings, high-power pulse generation, power system analysis, switchgear problems, betatron developments, electric discharge and fluorescent lamps, etc. Tours of the Company's works have also been arranged. The purpose of the school is to enable engineers in academic posts to obtain first-hand knowledge of the more important recent advances in electrical enginering ; attendance is by invitation of the Company. Further particulars can be obtained from the Manager, Publicity Department, British Thomson-Houston Co., Ltd., Rugby.

\section{Seventh International Congress of Food and Agricultural Industries}

THE Seventh International Congress of Food and Agricultural Industries will meet in Paris during July 12-18 at the invitation of the French Government. Among the subjects for discussion are: the role of vitamins, hormones and trace-substances, ionic exchanges in sugar-refining, fermentation, homologization of malt, bread-making qualities of wheats, rational use of the combined harvester, improvements in the dairying and canning industries, advances in the feeding of livestock, digestibility of fats and oils, destruction of organic matter in waste waters, standardization of statistical methods, and technical instruction. Further details can be obtained from the Commission Internationale des Industries Agricoles, 18 Avenue de Villars, Paris.

\section{University of London}

Tere following appointments in the University of London have been announced : Dr. G. C. McVittie, to the University chair of mathematics tenable at Queen Mary College as from October 1 ; since 1936 he has been reader in mathematics at King's College, but during the War was engaged on work at the Government Communications Headquarters. Dr. Sidney Smith, honorary professor of Near Eastern orchæology at the Institute of Archæology, London, to the University chair of ancient Semitic languages and civilizations tenable at the School of Oriental and African Studies, as from October 1.

The title of professor emeritus of physics in the University has been conferred on Dr. Frank Horton, professor of physics at Royal Holloway College during 1914-46 and vice-chancellor of the University during 1939-45. The title of professor emeritus of chemistry in the University has been conferred on Prof. T. S. Moore, professor of chemistry at Royal Holloway College during 1914-46.

The degree of D.Sc. has been conferred on Dr. Adrien Albert (School of Pharmacy), Louis Essen and A. E. J. Went.

\section{The Night Sky in July}

New moon occurs on July 6d. $21 \mathrm{~h} .09 \mathrm{~m}$., U.T., and full moon on July 21d. 02h. 31m. The following conjunctions with the moon take place: July 5d. 16h., Venus $8^{\circ}$ S.; July 5d. 18h., Mercury $8^{\circ} \mathrm{S}$.; July 9d. 06h., Saturn $4^{\circ}$ S.; July 11d. 16h., Mars $3^{\circ} \mathrm{S}$. ; July 18d. 0lh., Jupiter $4^{\circ} \mathrm{N}$. Mercury is too close to the sun in the early part of the month to be observed, but in the middle of the month the planet rises an hour before sunrise and attains its greatest westerly elongation on July 16. At the end of the month Mercury rises at $3 \mathrm{~h}$. $16 \mathrm{~m}$., about an hour before sunrise. Venus rises about a quarter of an hour before the sun on July 1 but can be observed later in the month, rising at $2 \mathrm{~h} .28 \mathrm{~m}$. and $1 \mathrm{~h} .4 \mathrm{~lm}$. on July 15 and 31, respectively. The planet attains its greatest easterly elongation on July 16 and its greatest brilliancy on July 31, when its stellar magnitude is $-4 \cdot 2$. Mars sets at $23 \mathrm{~h} .10 \mathrm{~m}$., 22h. $30 \mathrm{~m}$. and 21h. $45 \mathrm{~m}$. at the beginning, middle and end of the month, respectively, and can be seen for a short time in the western sky after sunset. Jupiter, in the constellation of Ophiuchus, is visible during the early part of the night, setting at $2 \mathrm{~h} .40 \mathrm{~m}$., $1 \mathrm{~h} .36 \mathrm{~m}$. and $0 \mathrm{~h} .33 \mathrm{~m}$. at the beginning, middle and end of the month, respectively. Owing to its large declination south, nearly $23^{\circ}$, the planet is not very well placed for observation in high northern latitudes. Saturn sets about an hour before Mars and cannot be observed very long after sunset; at the end of the month it sets a little more than half an hour after the sun. No occultations of stars brighter than magnitude 6 take place in July. The earth reaches aphelion on July 4, when its distance from the sun is $94,561,000$ miles.

\section{Announcements}

Dr. Julian Huxuey has been elected Correspondant for the Section of Anatomy and Zoology of the Paris Academy of Sciences.

THE honorary degree of D.Sc. of the University of Oxford has been conferred on Dr. Isaiah Bowman, president of Johns Hopkins University, and president during 1931-34 of the International Geographical Union; and on Prof. Linus Pauling, professor of chemistry and director of the Gates and Crellin Chemical Laboratories, California Institute of Technology, who is now George Eastman visiting professor at Oxford.

Mr. E. I. R. MACGREgor has been appointed assistant civil air attaché at the British Embassy, Washington, in succession to $\mathrm{Mr}$. N. Bicknell, who is entering the Foreign Service. Mr. MacGregor took first-class honours in physics at the Queen's University, Belfast, and after a short period on television research with Electric and Musical Industries, Ltd., he entered the R.A.F. Education Service (1936). During 1941-46 he served on the British Air Commission and R.A.F. Delegation at Washington.

A NEW exhibit of Protozoa in the Zoological Department of the British Museum (Natural History) has been opened to the public. It adjoins the Coral Gallery, which was reopened a few weeks ago. Owing to the minute size of these organisms, all but a few of the larger marine forms are displayed either by means of enlarged glass models or by tinted line drawings. 